Canadian

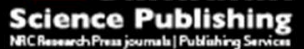

Canadian Journal of Civil Engineering Revue canadienne de génie civil

\title{
Evolution of the NBCC seismic provisions for operational and functional components in buildings
}

\begin{tabular}{|r|l|}
\hline Journal: & Canadian Journal of Civil Engineering \\
\hline Manuscript ID & cjce-2014-0219.R2 \\
\hline Manuscript Type: & Article \\
\hline Date Submitted by the Author: & 08-Jul-2015 \\
\hline Complete List of Authors: & $\begin{array}{l}\text { Assi, Rola; ETS, Génie de la construction } \\
\text { McClure, G.; McGill university, Civil Engineering and Applied Mechanics }\end{array}$ \\
\hline Keyword: & $\begin{array}{l}\text { construction < type of paper to review, state-of-the-art review < type of } \\
\text { paper to review, code formul \& safe cons < Struct. Eng. \& Constr. Mate, } \\
\text { response-earthquake load < Struct. Eng. \& Constr. Mate, structural < } \\
\text { Struct.Eng. \& Constr.Mate }\end{array}$ \\
\hline & \multicolumn{2}{|l}{} \\
\hline
\end{tabular}




\title{
Evolution of the NBCC seismic provisions for operational and functional components in buildings
}

\author{
Rola Assi and Ghyslaine McClure
}

Rola Assi ${ }^{1}$, École de Technologie Supérieure, Department of Construction Engineering, 1100, Notre-Dame West, Montreal, Québec, Canada, H3C 1K3.

Ghyslaine McClure, McGill University, Department of Civil Engineering and Applied Mechanics, 817 Sherbrooke Street West, Montreal, Québec, Canada, H3A 2K6.

${ }^{1}$ Corresponding author (e-mail: rola.assi@etsmtl.ca, Tel: (514) 396-8492, Fax: (514) 396-8584)

Word count

Abstract: 115

Total : $5300($ text $)+1750$ (figures) $=7050$ 
Abstract: This paper provides a summary of the evolution of the Canadian seismic design provisions for operational and functional components (OFCs) in buildings. The evolution of horizontal seismic force and displacement requirements in the National Building Code of Canada is presented and significant changes and parameters are discussed. Numerical examples illustrate the seismic design force levels as stipulated in recent editions of the NBCC for architectural, mechanical and electrical components attached at different elevations to buildings located in moderate and high seismic zones in Canada. Also, the seismic design force levels, computed according to different editions of the NBCC, are compared for a mechanical component and for an architectural component attached to buildings located in Vancouver.

Key words: Operational and functional components, non-structural elements, National Building Code of Canada, seismic force, seismic acceleration, seismic displacement, seismic risk

Résumé: Cet article résume l'évolution des normes canadiennes pour la conception parasismique des composants fonctionnels et opérationnels (CFO) des bâtiments. L'évolution des exigences du Code National du Bâtiment canadien quant aux forces sismiques horizontales et aux déplacements différentiels est présentée et les principaux paramètres et changements sont discutés. Des exemples numériques illustrent les niveaux de forces sismiques, tel que stipulé dans les éditions récentes du CNBC, pour des composants architecturaux, mécaniques et électriques. Une comparaison de ces forces sismiques, calculées selon les différentes éditions du CNBC, est présentée pour le cas précis d'un composant architectural et d'un composant mécanique attachés à des bâtiments situés à Vancouver.

Mots-clés: composants opérationnels et fonctionnels, éléments non-structuraux, Code National du Bâtiment canadien, force sismique, accélération sismique, déplacement sismique, risque sismique. 


\section{Introduction}

A building comprises various components that can be divided into two groups: structural components and operational and functional components (OFCs). The OFCs are those systems and elements housed or attached to floors, roofs, and walls of a building or industrial facility. Although they are not part of the main or intended load-bearing structural system, OFCs may still contribute to the structural integrity of the building, depending on their location, type of construction, and method of fastening. Some of the alternative names by which these systems are known are: non-structural components or elements, secondary systems, and building attachments. According to Chen and Soong (1988), secondary systems (that is OFCs) can be classified into non-structural secondary systems and structural secondary systems. For the latter type, concern is not only to their seismic behaviour, but also to their dynamic interaction with the primary structural system. Operational and functional components can generally be divided into three categories of sub-components according to CSA S832 (CSA 2014) and Villaverde (1997): architectural (internal like interior partition walls, ceilings and lighting fixtures and external like cladding and parapets), building or operational services including plumbing systems (like piping and sprinklers), mechanical systems (like heating, ventilation and air conditioning systems, and elevators), electrical systems (like electric generators, transformers, and battery racks), information technology and telecommunications (like telephone system, communication system, and cable trays) and building contents (common like supplies, computer systems, record storage, and specialized like fine arts, medical equipment and hazardous laboratory or medical materials). Globally, OFCs account for $75-85 \%$ of the original construction cost in commercial buildings as illustrated in Figure 1 (Miranda and Taghavi 2003). Therefore, their failure in an earthquake can not only result in important direct financial losses, but can significantly disrupt the function of the 
building and pose a safety risk to building occupants and passersby: OFCs are far from being secondary in importance when it comes to seismic risk analysis. A review of the typical damage sustained by various OFCs in recent earthquakes (including reviews by McKevitt et al. 1995; Kao et al. 1999; Naeim 1999; Naeim 2000; Filiatrault et al. 2001; Achour et al. 2011; Miranda et al. 2012) highlights the fact that the dysfunction/failure of OFCs is the greatest contributor to damage, losses and business interruption in most facilities. The vulnerabilities of OFCs in modern buildings were not clearly exposed until the $\mathrm{M}_{\mathrm{w}} 9.2$ march 27, 1964 Alaska and $\mathrm{M}_{\mathrm{w}} 6.6$ February 9, 1971 San Fernando earthquakes (Lagorio 1990). Experience has shown that in moderate earthquakes (1994 $\mathrm{M}_{\mathrm{w}} 6.7$ Northridge earthquake, CA; $2003 \mathrm{M}_{\mathrm{w}} 6.5$ San Simeon earthquake, CA; $2009 \mathrm{M}_{\mathrm{w}} 6.3$ L'Aquila earthquake, Italy; $2011 \mathrm{M}_{\mathrm{w}} 6.7$ Christchurch earthquake, $\mathrm{NZ}$ ), damage to critical equipment and contents is typically more important than damage to structural framework in buildings that abide by seismic code requirements. In active seismic zones, strong aftershocks exacerbate OFC damage.

In recent years, engineers, researchers, and building code committees have paid increasing attention to the seismic performance of secondary systems attached to primary building structures. Earthquake-resistant design of building structures is now a relatively mature discipline, and the seismic behaviour of OFCs is now considered a major factor to be accounted for while assessing the overall building performance and functionality. As a result, the seismic requirements for non-structural elements in the 2005 and 2010 editions (and the upcoming 2015 edition) of the NBCC are more detailed than in previous editions and include explicit provisions for more specific items (more categories of elements) that apply to facilities that require postearthquake functionality. The evolution of the NBCC seismic provisions for OFCs will be discussed in the following sections: it should be further noted that no significant changes have 
been implemented in the forthcoming 2015 edition of NBCC in terms of calculation of seismic force demand so that the 2010 edition can be considered as current.

\section{Evolution of the NBCC seismic design provisions for OFCs in new buildings}

This review of the recommended provisions in the different editions of NBCC is intended to reveal the variations in seismic design requirements for OFCs. Seismic design practice in Canada and in other countries has evolved significantly over the past seventy years, after the Second World War.

The first edition of the NBCC appeared in 1941 (NRCC 1941); it contained seismic provisions only in an appendix, based on the concepts presented in the 1937 United States Uniform Building Code (UBC) (Heidebrecht 2003). However, specific provisions for seismic design of structural components and OFCs in buildings and essential facilities were first introduced only in the 1953 edition. In all editions of the NBCC, the provisions concerning the OFCs are given in Part 4 (currently Division B) and Commentary J in the supplement of Part 4 (currently called the User's Guide).

\section{3 to 1965}

\section{Seismic force requirements}

In the 1953, 1960 and 1965 editions of NBCC (NRCC 1953, 1960, 1965), the seismic zoning map divided the country into four seismic regions based on earthquakes having a return period of 100 years (i.e. probability of 0.01 per annum). The minimum horizontal force for which portions of a building or structure should be designed to resist is given by:

[1] $V_{1953,1960}=C W$ 
Where $\mathrm{V}$ is the lateral seismic force in pounds, $\mathrm{W}$ is the total dead load tributary to the point where the earthquake force is to be calculated, including machinery and other fixed concentrated loads, $\mathrm{C}$ is a constant specified in the code for the part of the building being considered. The values of $\mathrm{C}$ are minimum and correspond to zone 1; they should multiplied by 2 for zone 2 and 4 for zone 3. The minimum values of $\mathrm{C}$ that correspond to zone 1 vary between 0.05 and 0.25 .

This simple equation was then refined in the 1965 edition to include more parameters to describe the $\mathrm{C}$ coefficient of Equation (1):

[2] $V_{1965}=\max (2 K ; 0.2 R g) * W$

\section{Where $\mathrm{K}=\mathrm{RCIFS}$.}

$\mathrm{K}$ takes into account the intensity of the earthquake in the area considered $(\mathrm{R})$, with values of 0 , 1,2 , and 4 for seismic zones $0,1,2$, and 3 respectively; the type of construction (C), with values of 0.75 for buildings having moment resisting frames or reinforced concrete shear walls and 1.25 for all other types of buildings; the importance of the building (I), with values of 1.3 for buildings having large assembly occupancies or which are important for well-being such has hospitals and power stations and 1.0 for all other buildings; the foundation conditions $(\mathrm{F})$ with values of 1.5 for buildings on highly compressible soil and 1.0 for all other sub-soil conditions; and the number of stories $\mathrm{N}$ of the building through the factor $\mathrm{S}$ where $\mathrm{S}=0.25 /(9+\mathrm{N})$.

These early editions of NBCC covered only the architectural components, towers, chimneys and tanks. In both the 1953 and 1960 editions, the same seismic force requirements apply to all building components (structural and non-structural), while the requirements of the 1965 edition are introduced in a separate clause and are more stringent for architectural components and 
curtain walls than for structural components by introducing the factor of 2 , which means that the seismic lateral force for OFCs is twice the force for structural components.

Starting from the 1965 edition, dynamic analysis was mentioned as an alternative to simple static analysis for earthquake-resistant design. However, no details were provided about the definition of dynamic analysis methods.

Also, in these early editions of NBCC, the OFC seismic risk was not associated with a probability level.

\section{Seismic displacement requirements}

In these early editions of the $\mathrm{NBCC}$, there were no provisions related to displacements. 1970

\section{Seismic force requirements}

The 1970 edition of NBCC (NRCC $1970 \mathrm{a}, \mathrm{b}$ ) introduced a more refined seismic contour map of the country based on expected ground accelerations having a return period of 100 years. The new map was based on the analysis of past earthquakes (1899-1963) throughout the country. Building parts and portions (this is when the subscript $\mathrm{p}$ was introduced) and their anchorage to the supporting structure were then required to be designed for a minimum lateral force given by:

[3] $V_{1970}=\frac{1}{4} R C_{p} W_{p}$

Where $\mathrm{W}_{\mathrm{p}}$ is the weight of the part or portion of a structure, such as cladding, wall partitions and appendages; $\mathrm{R}$ is the seismic regionalization factor, which is a measure of the seismic activity and hazard in the area considered (it is equal to 4 in zone 3, 2 in zone 2, 1 in zone 1 and 0 in zone 0 ); and $\mathrm{C}_{\mathrm{p}}$ is the horizontal force factor for the part or portion of the structure (varying from 0.1 
to 2). Interestingly, the importance of the building, introduced with the I factor in 1965 was not considered for OFCs in this later edition.

In the commentary to the 1970 edition, it was noted that machinery and electrical/mechanical components mounted within buildings should be designed to withstand the forces and displacements that arise from the seismic response of the structure, but no further specific provisions were given.

\section{Seismic displacement requirements}

In this edition, although there were no specific provisions for seismic displacement, it was recommended in the commentary that the interstory drift be limited to $0.005 \mathrm{~h}_{\mathrm{s}}$, where $\mathrm{h}_{\mathrm{s}}$ is the story height. It was also noted there that the deflections obtained from an elastic (static) analysis using the lateral force determined in Equation (3) should be multiplied by 3 .

\section{5 and 1980}

\section{Seismic force requirements}

In these editions of NBCC (NRCC 1975a, b, 1980a, b), the same zoning maps as of the 1970 edition were used. A new equation was proposed for the minimum seismic lateral force for buildings parts and their anchorage:

[4] $V_{1975,1980}=A S_{p} W_{p}$

Where $\mathrm{A}$ is the acceleration ratio or assigned horizontal design acceleration as a fraction of $\mathrm{g}$, assumed constant over each seismic zone; and $S_{p}$ is the horizontal force factor for the part or portion of the building.

It is in these NBCC editions that specific $S_{p}$ factors for machinery and electrical/mechanical components mounted within buildings were introduced for the first time. The range of variation 
of the factor was from 1.0 to 25 . The building importance factor was not taken into account in this edition. The type of OFC connection to the structure, flexible or rigid, was not considered either.

\section{Seismic displacement requirements}

The requirements were unchanged from the 1970 edition.

\section{5}

\section{Seismic force requirements}

In the 1985 edition of NBCC (NRCC 1985a, b), new seismic zoning maps were introduced, dividing the country into seven acceleration and velocity related zones. The new maps were based on a much lower probability of exceedence, $10 \%$ in 50 years (i.e. 0.0021 per annum compared to 0.010 in previous editions). In this edition, the minimum lateral force for which buildings parts and their anchorage shall be designed is given by:

[5] $V_{1985}=v S_{p} W_{p}$

Where $v$ is the zonal velocity ratio expressed as a ratio of the specified zonal horizontal ground velocity to $1 \mathrm{~m} / \mathrm{s}$; and $S_{p}$ is the horizontal force factor for the part or portion of a structure. Higher $S_{p}$ factors were introduced for machinery, equipment and pipes that are not rigid or rigidly connected, varying from 0.9 to 11 , while the type of connection was not addressed in the previous editions of NBCC.

\section{Seismic displacement requirements}

The same requirements of the 1970 edition of NBCC were used. 
1990

\section{Seismic force requirements}

The same zoning maps as in the NBCC 1985 edition were used (NRCC 1990a, b) and the equation to calculate the lateral seismic force demand was unchanged as well:

[6] $V_{1990}=v S_{p} W_{p}$

However, there were refinements in the evaluation of the horizontal force factor, $\mathrm{S}_{\mathrm{p}}$, for various types of components. For architectural components, the values of $\mathrm{S}_{\mathrm{p}}$ vary between 0.7 and 6.5 , while for mechanical/electrical components an equation is introduced as:

$\mathrm{S}_{\mathrm{p}}=\mathrm{C}_{\mathrm{p}} \mathrm{A}_{\mathrm{r}} \mathrm{A}_{\mathrm{x}}$

where $A_{x}$ is the amplification factor at floor level $x$ to account for variation of response of the mechanical/electrical component according to its location along the building elevation; $A_{x}$ is equal to $\left(1+h_{x} / h_{n}\right)$ where $h_{x}, h_{n}$ are the heights above ground at levels $x$ or $n$ respectively (level $n$ is the roof level); the maximum value of $\mathrm{A}_{\mathrm{x}}$ at roof level is $2.0 ; \mathrm{A}_{\mathrm{r}}$ is the response amplification factor to account for the type of attachment of mechanical/electrical component, it is is equal to 1.0 for components that are both rigid and rigidly connected, 2.0 for flexible components or flexibly mounted components located on ground, and 4.5 for all other cases; $\mathrm{C}_{\mathrm{p}}$ is the seismic coefficient for mechanical/electrical components, whichvaries from 0.7 to 1.5 .

In this edition, the provisions for mechanical/electrical components are more elaborate and rational than in previous editions, namely with the introduction of the $A_{r}$ and $A_{x}$ factors. The provisions for architectural components remained practically unchanged except for the increase in the $S_{p}$ values. 


\section{Seismic displacement requirements}

A major change was introduced for so-called post-disaster buildings such as hospitals, police and fire stations, and other buildings related to public safety that must remain functional during and immediately after an earthquake with a $0.01 \mathrm{~h}_{\mathrm{s}}$ limit on the interstory drift at any level, based on the lateral deflections obtained from linear elastic analysis. The value of $0.02 \mathrm{~h}_{\mathrm{s}}$ remained unchanged for all other buildings. Instead of specifying a fixed value of 3.0 to multiply the lateral deflections obtained from elastic analysis, as stiuplated in the previous edition, a factor $\mathrm{R}$ was introduced to give more realistic values of anticipated deflections. $\mathrm{R}$ reflects the capacity of the structure to dissipate energy through inelastic behavior, and suggested values varied from 1.0 to 4.0.

1995

The NBCC 1995 (NRCC 1995a, b) had the same earthquake design hazard levels and the same zoning maps as its previous edition.

\section{Seismic force requirements}

The provisions for building parts and portions are similar to those of the 1985 edition of NBCC, which introduced a distinction in force requirements for architectural components and for mechanical and electrical equipment. The lateral force, $V_{p}$, is taken as :

[7] $V_{p}=v I S_{p} W_{p} \quad$ For architectural components

[8] $V_{p}=v I C_{p} A_{r} A_{x} W_{p} \quad$ For mechanical/electrical components

The importance factor I is introduced again, to establish compatibility of design risks with the structural system of post-disaster buildings $(\mathrm{I}=1.5)$ and schools $(\mathrm{I}=1.3)$. $\mathrm{A}_{\mathrm{r}}$ is equal to 1.0 for 
components that are both rigid and rigidly connected and for non-brittle pipes and ducts, 1.5 for components located at ground level that are flexible or flexibly connected except for non-brittle pipes and ducts and 3.0 for all other cases.

The seismic design forces in the 1995 edition differ from the earlier editions of the NBCC due to several reasons (Tauby et al. 1999): 1) earthquake, geological, and tectonic information was analyzed using a new seismic risk approach; 2) newly developed strong ground motion attenuation relations were included; and 3) both horizontal acceleration and horizontal velocity have been considered.

\section{Seismic displacement requirements}

The requirements in the 1995 edition are the same as those given in the 1990 edition.

\section{5 and 2010}

The formulation of the 2005 and 2010 provisions (NRCC 2005a,b; NRCC 2010a,b) for OFCs is based on the uniform hazard spectrum approach used for the design of structures (Adams and Halchuck 2003; Adams J. and Atkinson G. 2003). The new uniform hazard spectrum model and resulting maps account for soil type and near-fault effects since they incorporate a significant amount of new earthquake data, recent research on source zones and earthquake occurrence, together with complementary research on strong ground motion relations. In contrast to the 1985 maps, which gave values for peak horizontal ground velocity and peak horizontal ground acceleration, peak horizontal spectral acceleration values $\left(\mathrm{S}_{\mathrm{a}}(\mathrm{T}) ; 5 \%\right.$ damped) are now directly specified, where $\mathrm{T}$ is the period of the building structure. The seismic hazard at the site of the structure is included in the design force formula through the spectral acceleration value $S_{a}(0.2)$, which is taken from the uniform hazard spectrum at $0.2 \mathrm{~s}$ period. It is assumed that most nonstructural components in buildings are stiff or rigid (which is far from true in many instances), 
and research from past earthquakes has shown that the forces on such components correlate most closely with this $\mathrm{S}_{\mathrm{a}}(0.2)$ acceleration ordinate (NEHRP 2009).

The 2005 and 2010 provisions use site values for design instead of zone values as used in previous editions of NBCC. They are based on a probability of exceedence of $2 \%$ in 50 years (instead of $10 \%$ in 50 years in previous editions), corresponding to a return period of approximately 2500 years. Site class C (very dense soil or soft rock) was adopted as a reference for reasons summarized in Adams and Halchuck (2003).

\section{Seismic force requirements}

These provisions (currently in effect) use the same generic equation to describe the lateral force requirements for architectural components and for mechanical and electrical components. Elements and components of buildings and their connections shall be designed for a lateral force $V_{p}$ given by:

[9] $V_{p}=0.3 F_{a} S_{a}(0.2) I_{E} S_{p} W_{p}$

Where $\mathrm{F}_{\mathrm{a}}$ is the acceleration-based site coefficient that varies from 0.7 to 1.4 . It is function of site class and $\mathrm{S}_{\mathrm{a}}(0.2) ; \mathrm{S}_{\mathrm{a}}(0.2)$ varies from 0.12 (Inuvik) to 1.2 (Victoria). $\mathrm{I}_{\mathrm{E}}$ is the importance factor for the building and it can take values of $1,1.3$ or 1.5. The same equation for horizontal force factor, $\mathrm{S}_{\mathrm{p}}$, is now introduced for all component types:

$\mathrm{S}_{\mathrm{p}}=\mathrm{C}_{\mathrm{p}} \mathrm{A}_{\mathrm{r}} \mathrm{A}_{\mathrm{x}} / \mathrm{R}_{\mathrm{p}}$

The maximum value of $S_{p}$ is 4.0 and its minimum value is $0.7 . C_{p}$ is the element or component factor specified for different types of components. It considers the risk to life safety associated with failure of the component and release of contents if applicable; $C_{p}$ varies from 0.7 for low risk and 1.5 for high risk. $\mathrm{R}_{\mathrm{p}}$ is the element or component response modification factor that is 
introduced for the first time to account for the energy-absorption capacity of the element and its attachment; $R_{p}$ varies from 1.25 to $5 . A_{r}$ is the element or component force amplification factor to account for possible dynamic tuning between the building and the component, and is function of the ratio of the natural frequencies of the component and the structure; $\mathrm{A}_{\mathrm{r}}$ varies from 1.0 to 2.5. $\mathrm{A}_{\mathrm{x}}$ is the height factor; a linear amplification of acceleration through the height of the building is assumed such that $A_{x}$ is equal to $\left(1+2 h_{x} / h_{n}\right)$. It ishould be noted that the maximum value of $A_{x}$ at rooftop level is now 3.0 compared to the value of 2.0 in the 1995 edition of NBCC. In this edition, the height factor is considered for the first time for architectural components.

\section{Seismic displacement requirements}

Some refinements have been introduced compared to 1995. While the largest interstory drift at any level based on the lateral deflections obtained from linear elastic analysis is still limited to $0.010 \mathrm{~h}_{\mathrm{s}}$ for post-disaster buildings $\left(\mathrm{I}_{\mathrm{E}}=1.5\right)$, the revised provisions indicate a new limit of 0.02 $\mathrm{h}_{\mathrm{s}}$ for schools $\left(\mathrm{I}_{\mathrm{E}}=1.3\right)$ and a more relaxed limit of $0.025 \mathrm{~h}_{\mathrm{s}}$ for all other buildings of normal importance $\left(\mathrm{I}_{\mathrm{E}}=1\right)$. The lateral deflections obtained from an elastic analysis are to be multiplied by $R_{d} R_{o} / I_{E}$ to give realistic values of anticipated deflections, where $R_{o}$ is the force overstrength factor (varying between 1.0 and 1.7 depending on the lateral load resisting system) and $R_{d}$ represents the energy dissipation capacity of the element or its connections (varying between 1.0 and 5.0 depending on the lateral load resisting system).

\section{Comparison of the seismic force requirements for the $2005 / 2010$ and the 1995 editions of}

\section{the NBCC}

In the following, we present design forces for mechanical/electrical components, and for architectural components in a normal importance category building $\left(\mathrm{I}_{\mathrm{E}}=1\right)$ located in Vancouver 
(high seismic zone) and Montreal (moderate seismic zone) according to the 1995, 2005 and 2010 editions of the NBCC, so that one can assess the impact of code changes on the seismic design force levels at specific locations. The indicator is the ratio of the lateral seismic force, $V_{p}$, to the component weight, $W_{p}$. The values are taken at ground level, middle and rooftop of a regular four-storey building.

\section{Mechanical/electrical components}

The NBCC 2005/2010 and 1995 provisions give close values for $V_{p} / W_{p}$ ratio at the ground floor level for mechanical/electrical components located in Vancouver and Montreal (Figures 2a and 3a). At the upper floor levels, the 1995 seismic design forces are higher than the 2005/2010 forces for most components, especially in Vancouver (Figures $2 \mathrm{~b}$ and 2c),.except for rigid/rigidly attached components. In Montreal (Figures $3 \mathrm{~b}$ and 3c), the forces are similar at the mid-height and rooftop of the building, except for rigid/rigidly attached components.

\section{Architectural components}

The NBCC 1995 seismic design forces of architectural components are higher than those of the 2005/2010 editions at ground level for all components in both Vancouver and Montreal seismic zones (Figures 4a and 5a). The difference is less noticeable at the rooftop level, especially in Montreal, except for cantilevered components (Figures $4 \mathrm{~b}$ and $5 \mathrm{~b}$ ).

It is seen that the NBCC 1995 provisions yield conservative forces for architectural components at ground level, especially in high seismic zones, whereas this conservatism is less considerable and not systematic at the upper levels, particularly in moderate seismic zones. Therefore, the conservatism in the $1995 \mathrm{NBCC}$ provisions for architectural components is somewhat proportional to the seismic hazard level. 
Numerical examples for calculation of seismic forces according to (1970-2010) editions of the NBCC

In order to illustrate the evolution of the NBCC seismic force requirements for the OFCs over the years, forces were computed for an architectural component and a mechanical component assumed to be attached to buildings located in Vancouver that is considered a high seismic zone for Canada.

\section{Architectural component}

This example of architectural OFC is a suspended acoustic ceiling system rigidly connected to the structure of an office occupancy building $\left(\mathrm{I}_{\mathrm{E}}=1\right)$, it is the same component as used in Figures 4 and 5.Calculations were done at the ground floor and the rooftop levels. Figures $6 \mathrm{a} \& 6 \mathrm{~b}$ show that the variation in the force requirements was not uniform over the years, and, as mentioned before, the latest editions of NBCC 2005/2010 are less stringent for architectural components, especially at the ground floor. The variation in the force levels in the early editions is mainly attributed to the variation in the $S_{p}$ values in different versions of NBCC, where conservative $S_{p}$ values were initially proposed in order to cover a wide range of components. Starting from 1995, reduced $S_{p}$ values were proposed specifically for suspended ceilings; this is a counterintuitive trend as several major recent earthquakes have triggered numerous failures of suspended ceiling systems.

\section{Mechanical component}

This example is a rooftop chiller on vibration isolators (flexible connection) attached to the rooftop of a hospital $\left(\mathrm{I}_{\mathrm{E}}=1.5\right)$, it is the same component as used in Figures 2 and 3 but with a different importance factor for the building. Figure 7 shows that the variation in the force requirements was not uniform over the years. Until 1980, no distinction was made between rigid 
and flexible components; therefore, the forces were conservatively increased through the different editions. The decrease in the force level in 1985 is attributed to lower acceleration and $\mathrm{S}_{\mathrm{p}}$ values. Higher design force levels in 1990 and 1995 are attributed to the introduction of the height and importance factors in the equation. Even though there was an increase in the height amplification factor in the $2005 / 2010$ provisions, seismic force levels are lower than those of the 1995 provisions due to the introduction of $R_{p}$ factors that account for the the ductility and overstrenght, the nonlinear OFC response is reflected by the upper limits for $S_{p}$, and lower $A_{r}$ factors.

\section{Conclusion}

In this paper, the authors surveyed the evolution of the NBCC seismic force and displacement requirements for mechanical, electrical and architectural components. Substantial differences between the seismic design requirements in different NBCC editions (1953-2010) were emphasized and numerical examples of two acceleration-sensitive components (a suspended acoustic ceiling and a rooftop chiller) were used to illustrate the variations in the design force levels over the years. These variations are not uniform, but have a decreasing trend starting from the 1990 edition since there were significant improvements in the equations used to compute the seismic forces. Some of the differences in the force calculations are also attributed to the variations in the design ground motion specified over several decades based on seismicity models of various degrees of sophistication. It is noteworthy to mention that ground motion specifications have also changed slightly between the 2005 and 2010 editions of the Code, for Eastern Canada in particular. More of these adjustments are also to appear in the 2015 edition. All in all, it is not evident to compare sesimic force requirements when such parameters vary from one edition to the next. To get a better grasp of the variations in sesimic force demands, a 
comparison of seismic force levels for various acceleration-sensitive components was done between the 1995 and 2005/2010 NBCC provisions for a building assumed to be located in Vancouver and Montreal, to consider high and moderate levels of seismic activity, respectively. It was observed that the difference between the seismic force demands is more pronounced for architectural components (the suspended ceiling example) especially at the ground level. On the other hand, the difference is not significant for mechanical/electrical components attached to buildings located in moderate seismic zones, while this difference becomes noticeable in high seismic zones, especially for components attached above the ground floor. 


\section{References}

Achour N., Miyajima Masakatsu, Kitaura M., and Price A. 2011. Earthquake-induced structural and non-structural damage in hospitals. Earthquake Spectra, 27(3): 617-634.

Adams J., and Atkinson G. 2003. Developments in Seismic Hazard Maps for Building Code Applications in Canada. Canadian Journal of Civil Engineering, 30(2): 255-271.

Adams, J., and Halchuck, S. 2003. Fourth generation seismic hazard maps of Canada: Values for over 650 Canadian localities intended for the 2005 National Building Code of Canada. Geological Survey of Canada Open File 4459, Ottawa, ON.

Chen, Y., and Soong, T. T. 1988. Seismic response of secondary systems. Engineering Structures, 10(4): 218-228.

CSA S832. 2014. S832-14: Seismic risk reduction of operational and functional components (OFCs) of buildings. Canadian Standards Association, Mississauga, ON, 134 p.

Filiatrault, A., Uang, C.-M., Folz, B., Christopoulos, C., and Gatto, K. 2001. Reconnaissance report of the February 28, 2001 Nisqually Seattle-Olympia) earthquake. Department of structural engineering, University of California, San Diego, La Jolla, CA.

Heidebrecht, A. C. 2003. Overview of seismic provisions of the proposed 2005 edition of the National Building Code of Canada. Canadian Journal of Civil Engineering, 30(2): 241-254.

IBC. 2000. International building code 2000, International code council, Fall, Church, VA.

Kao, Andrew S., Soong, T. T., and Amanda, V. 1999. Nonstructural damage database. Report MCEER-99-0014, Multidisciplinary Center for Earthquake Engineering, Buffalo, New York.

Lagorio, H.J. 1990. An architect's guide to nonstructural damage, John Wiley \& Sons, New York. McKevitt, W. E. 2003. Proposed Canadian code provisions for seismic design of structures, nonstructural components and equipment. Canadian Journal of Civil Engineering, 30(2): 366-377. 
McKevitt, W. E., Timler, P. A. M., and Lo, K. K. 1995. Nonstructural damage from the Northridge earthquake. Canadian Journal of Civil Engineering, 22(2): 428-437.

Miranda, E., and Taghavi, S. 2003. Estimation of seismic demands on acceleration-sensitive nonstructural components in critical facilities. Proceedings of ATC-29-2 Seminar on Seismic Design, Performance, and Retrofit of Nonstructural Components in Critical Facilities, ATC29-2 Report, Applied Technology Council, California

Miranda E., Gilberto M., Rodrigo R., and Gokhan P. 2012. Performance of nonstructural components during the 27 February 2010 Chile Earthquake. Earthquake Spectra, 28(S1): S453-S471.

Naeim, F. 1999. Lessons learned from performance of nonstructural components during the January 17, 1994 Northridge earthquake--Case studies of six instrumented multistory buildings. Journal of seismology and earthquake engineering, 2(1): 45-57.

Naeim, F. 2000.Learning from structural and nonstructural seismic performance of 20 extensively instrumented buildings. Proceedings of the $12^{\text {th }}$ World Conference on Earthquake Engineering, Auckland, New Zealand.

NEHRP. 2009. NEHRP recommended provisions for seismic regulations for new buildings and other structures Parts 1\&2), Building Seismic safety Council, Washington, D.C.

NRCC. 1941. National Building Code of Canada, National Research Council of Canada, Ottawa, ON.

NRCC. 1953. National Building Code of Canada, National Research Council of Canada, Ottawa, ON.

NRCC. 1960. National Building Code of Canada, National Research Council of Canada, Ottawa, ON.NRCC. 1965. National Building Code of Canada, National Research Council of Canada, 
Ottawa, ON.NRCC. 1970a. National Building Code of Canada, National Research Council of Canada, Ottawa, ON.

NRCC. 1970b. Part 4: Commentary on the National Building Code of Canada, National Research Council of Canada, Ottawa, ON.NRCC. 1975a. National Building Code of Canada, National Research Council of Canada, Ottawa, ON.NRCC. 1975b. Part 4: Commentary on the National Building Code of Canada, National Research Council of Canada, Ottawa, ON.

NRCC. 1980a. National Building Code of Canada, National Research Council of Canada, Ottawa, ON.

NRCC. 1980b. Part 4: Commentary on the National Building Code of Canada, National Research Council of Canada, Ottawa, ON.

NRCC. 1985a. National Building Code of Canada, National Research Council of Canada, Ottawa, ON.

NRCC. 1985b. Part 4: Commentary on the National Building Code of Canada, National Research Council of Canada, Ottawa, ON.

NRCC. 1990a. National Research Council of Canada, National Research Council of Canada, Ottawa, ON.

NRCC. 1990b. Part 4: Commentary on the National Building Code of Canada, National Research Council of Canada, Ottawa, ON.

NRCC. 1995a. National Building Code of Canada, National Research Council of Canada, Ottawa, ON.

NRCC. 1995b. Part 4: Commentary on the National Building Code of Canada, National Research Council of Canada, Ottawa, ON. 
NRCC.2005a. Proposed provisions of the National Building Code of Canada, National Research Council of Canada, Ottawa, ON.

NRCC. 2005b. Part 4: Commentary on the National Building Code of Canada, National Research Council of Canada, Ottawa, ON.

NRCC. 2010. Proposed provisions of the National Building Code of Canada, National Research Council of Canada, Ottawa, ON.

NRCC. 2010b. Part 4: Commentary on the National Building Code of Canada, National Research Council of Canada, Ottawa, ON.

Tauby, J. R., Lloyd, R., Noce, T., and Tunnissen, J. 1999. Practical guide to seismic restraint, American society for heating, refrigerating, and air-conditioning engineers, Inc., Atlanta, GA.

Villaverde, R. 1997. Seismic design of secondary structures: State of the art. ASCE Journal of Structural Engineering, 123(8): 1011-1019. 


\section{List of figures}

Figure 1 Typical fraction of direct costs in building construction (Miranda and Taghavi 2003)

Figure 2 Comparison of forces for mechanical/electrical components according to NBCC 1995, 2005/2010 provisions, Vancouver: a) ground floor, b) middle floor, c) rooftop

Figure 3 Comparison of forces for mechanical/electrical components according to NBCC 1995, 2005 and 2010 provisions, Montreal: a) ground floor, b) middle floor, c) rooftop

Figure 4 Comparison of forces for architectural components according to NBCC 1995, 2005/2010 provisions, Vancouver: a) ground floor, b) rooftop

Figure 5 Comparison of forces for architectural components according to NBCC 1995, 2005 and 2010 provisions, Montreal: a) ground floor, b) rooftop

Figure 6 Comparison of forces for an architectural component in Vancouver according to NBCC (1970-2010): a) ground floor, b) rooftop

Figure 7 Comparison of forces for a rooftop mechanical component in Vancouver according to NBCC (1975-2010) 


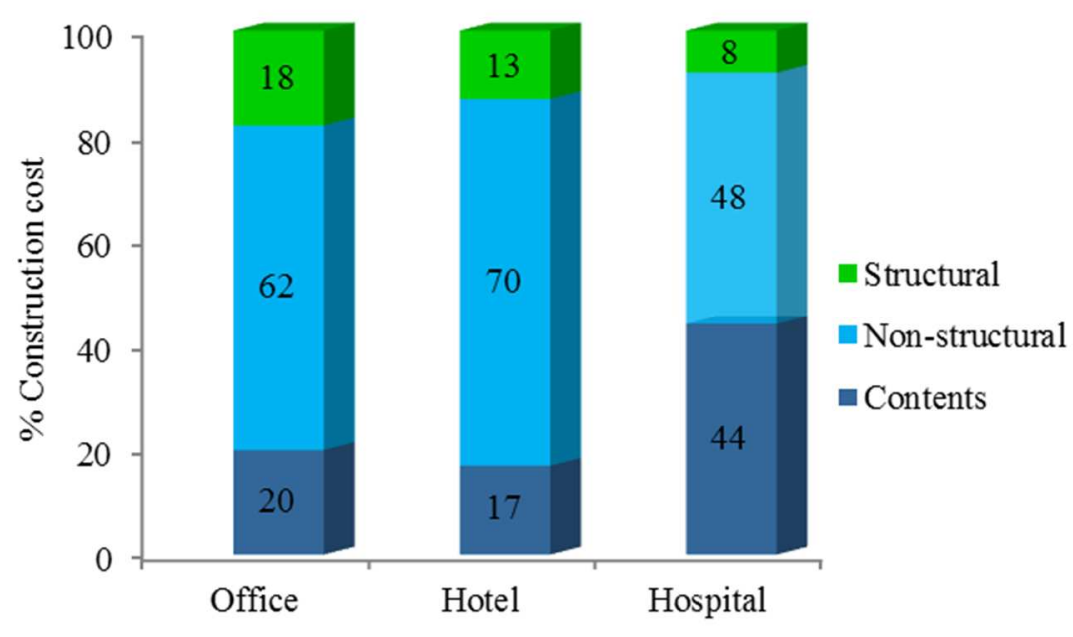



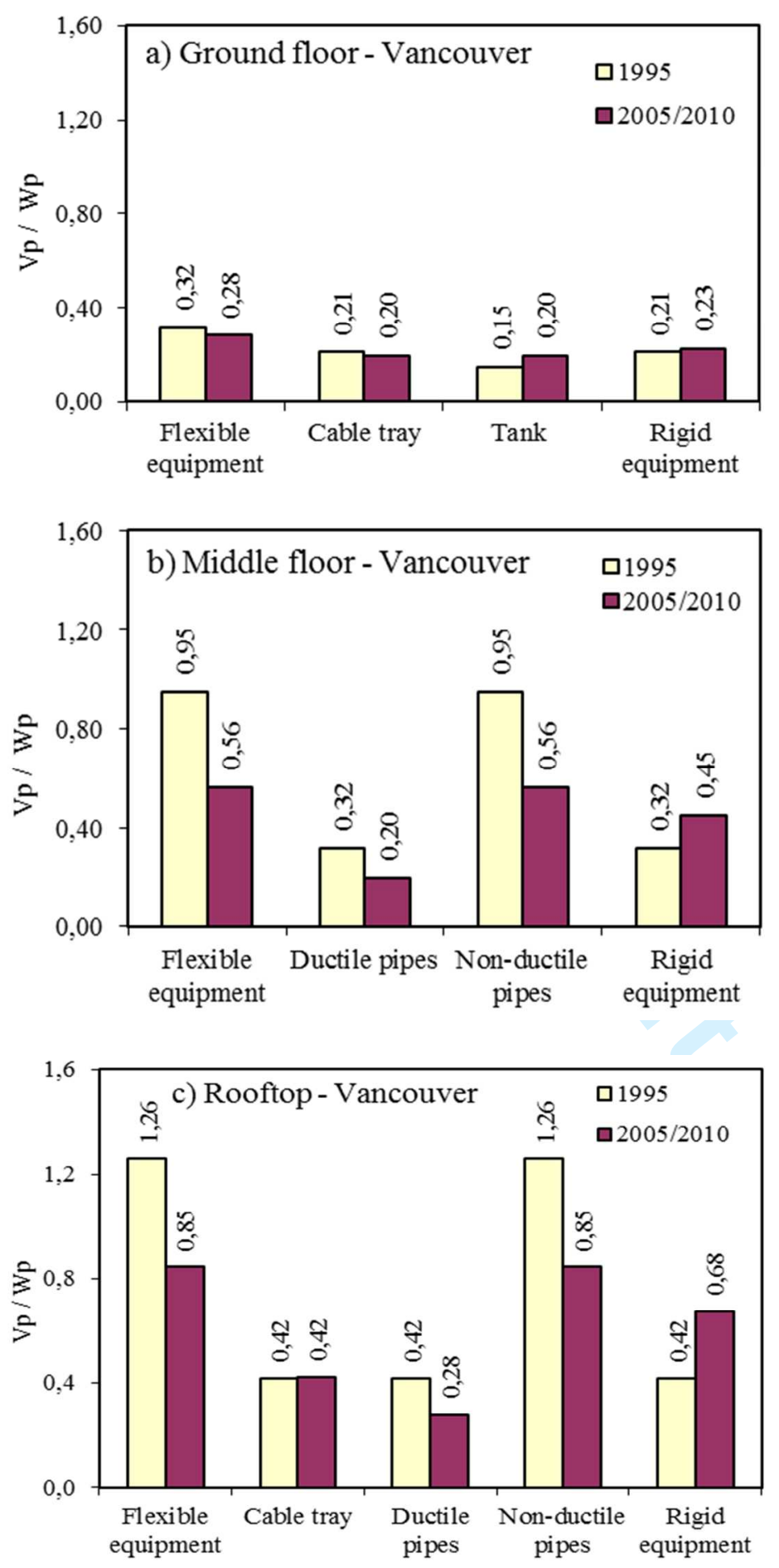

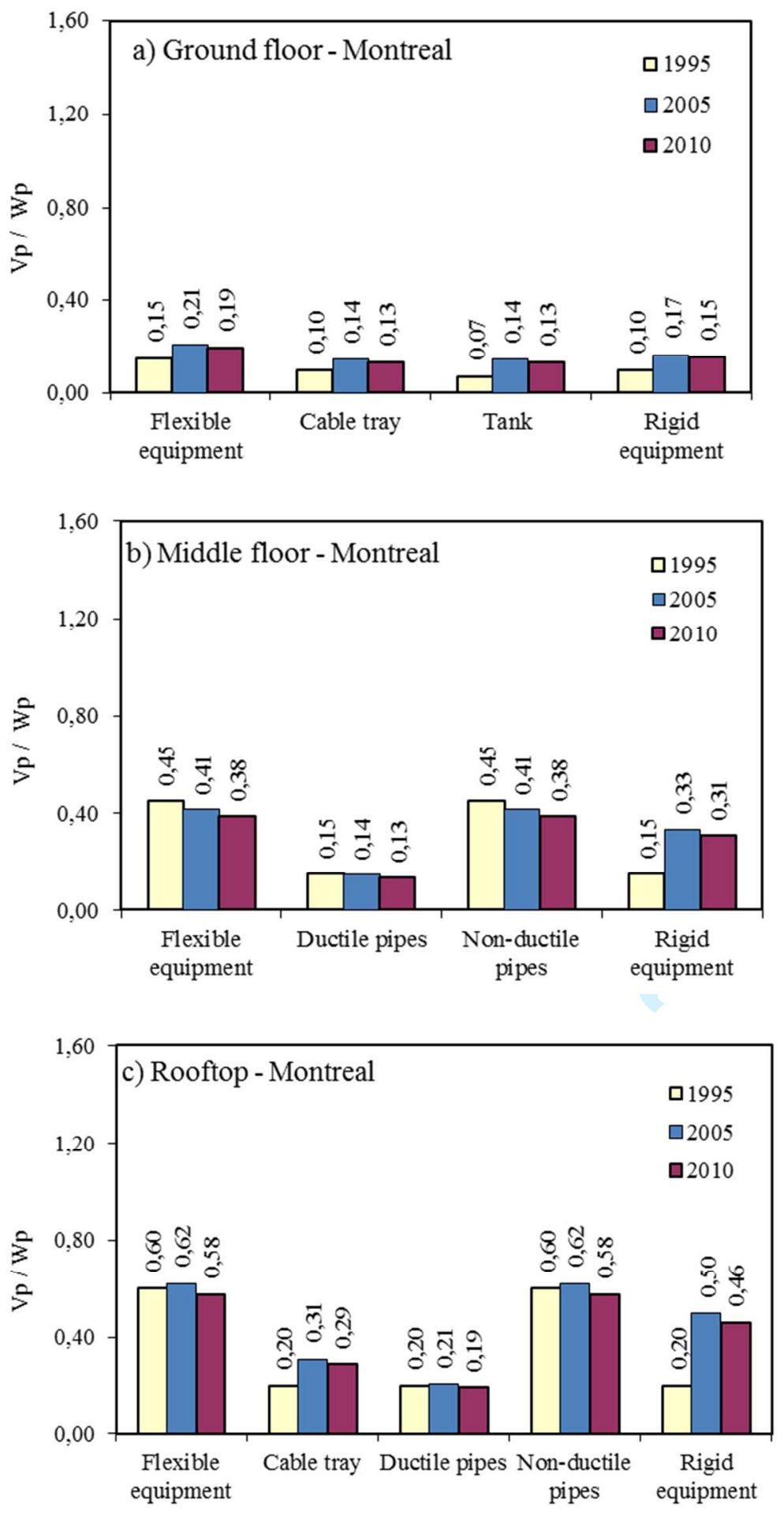

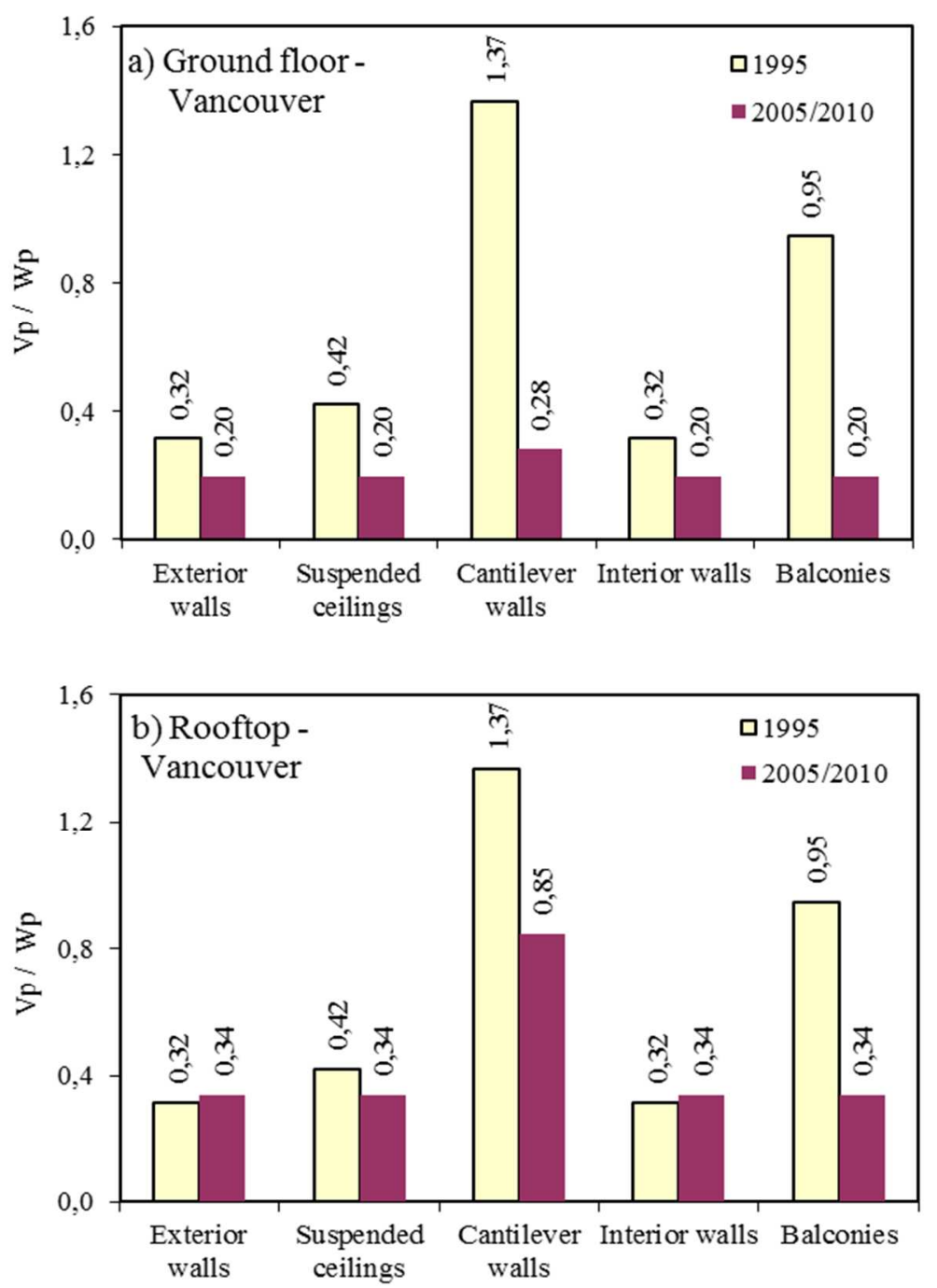

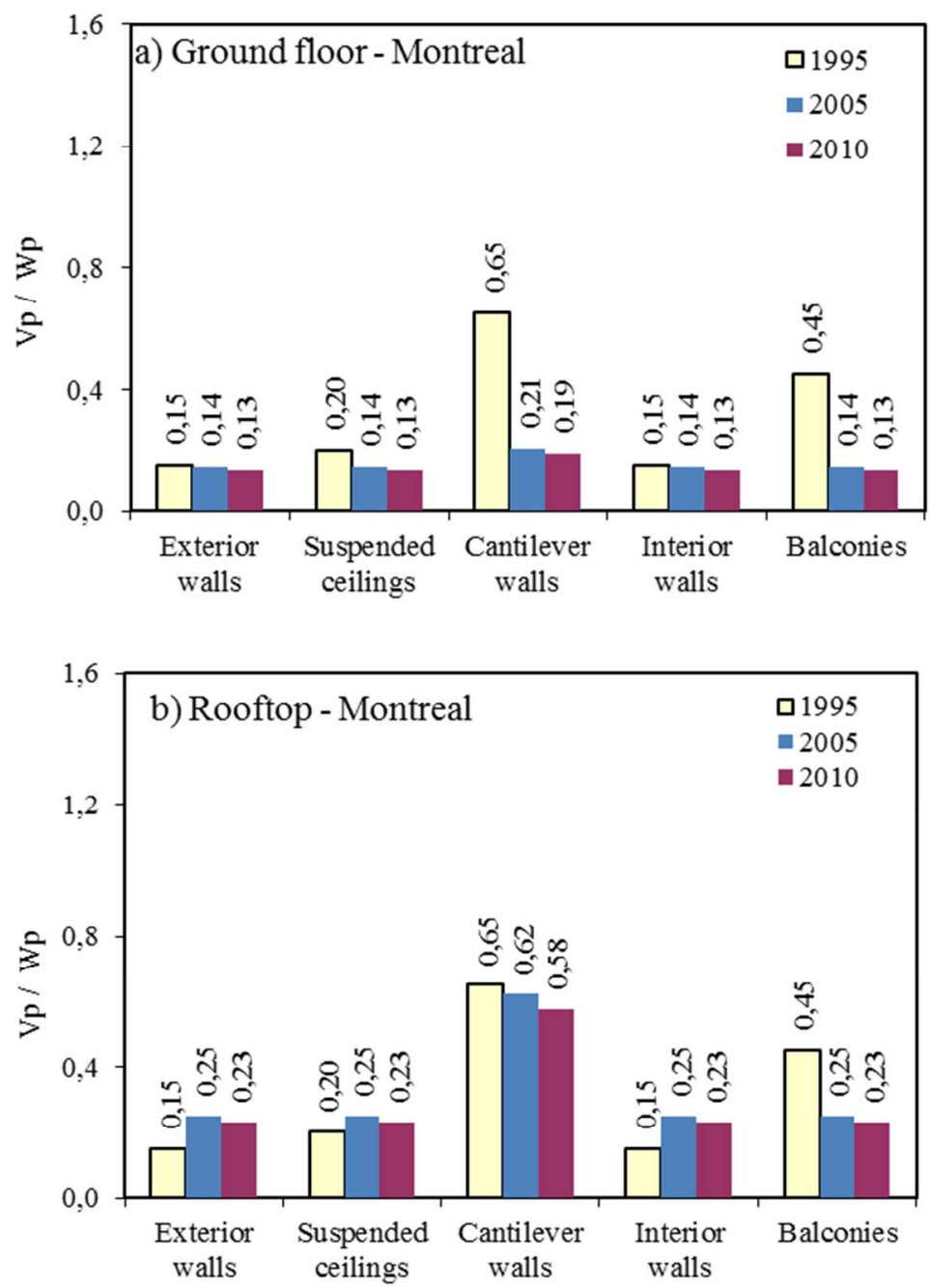

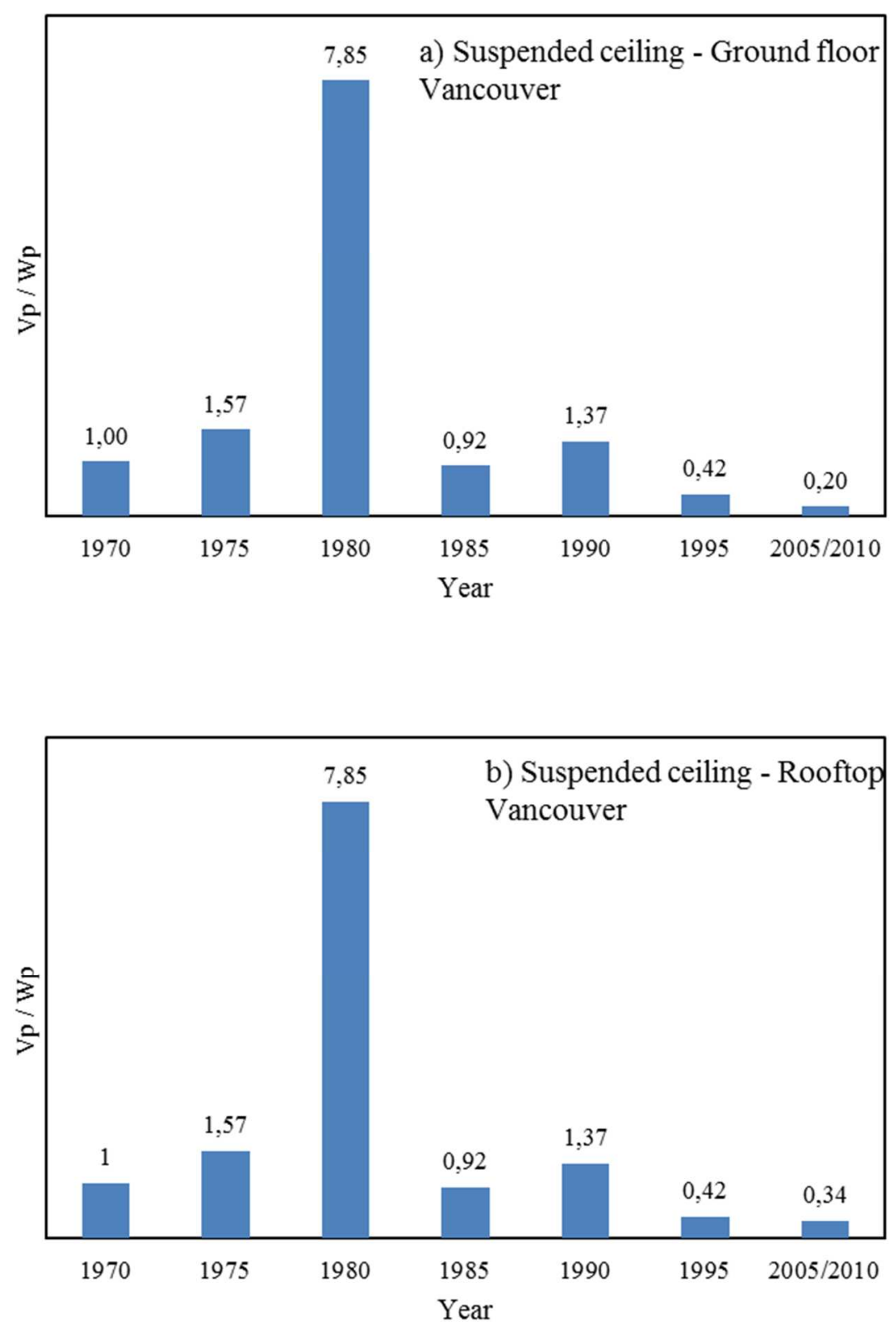


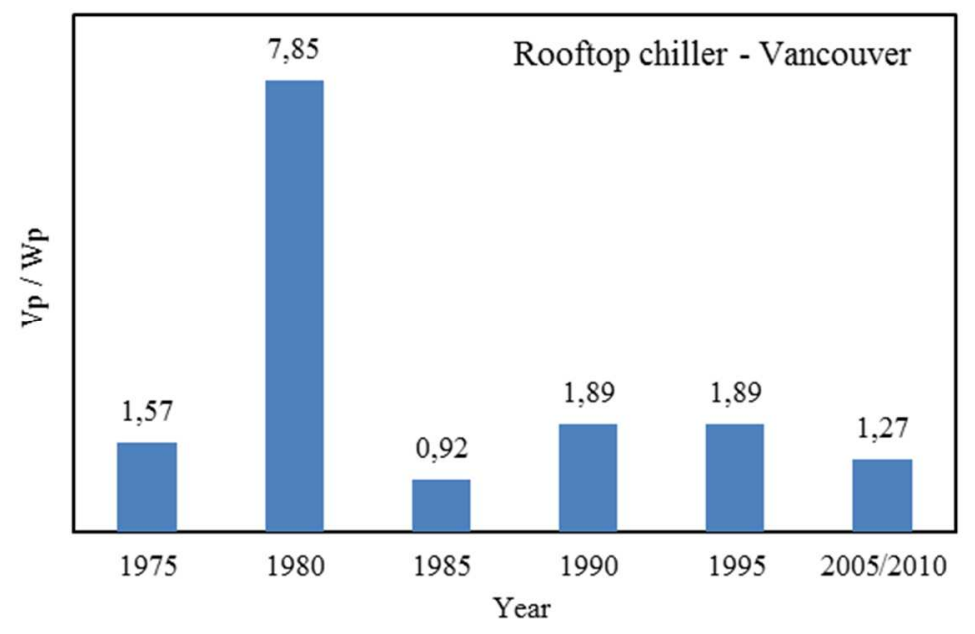

https://mc06.manuscriptcentral.com/cjce-pubs 